\title{
PERAN DEWAN PERWAKILAN RAKYAT DAERAH DALAM PENGAWASAN TERHADAP JALANNYA OTONOMI DAERAH DI KABUPATEN LAMONGAN
}

\author{
Oleh : Bambang Muljono, SH, S.pN, M.Hum, MM
}

\begin{abstract}
Abstrak
Dewan Perwakilan Rakyat Daerah adalah merupakan salah satu unsur Pemerintah Daerah yang keaggotaannya mencerminkan kondisi perwakilan rakyat daerah yang diwujudkan dalam fraksifraksi dan bersama-sama dengan Kepala Daerah menjalankan tugas dan wewenang Pemerintah Daerah di bidang legislatif. Keberadaan Lembaga Legislatif Daerah telah mengalami perubahan dan pengembangan yang sangat pesat, baik dari segi hukumnya maupun dari segi praktek lembaga daerah itu sendiri. Sebagai wakil rakyat di daerah, maka DPRD mempunyai tanggung jawab yang besar dalam mengemban aspirasi rakyat yang diwakilinya. Pembentukan Badan Perwakilan Rakyat Daerah dapat pula dikatakan sebagai perwujudan dari Pasal 18 UUD 1945 yang lebih lanjut diatur dalam Undang-Undang organiknya, yaitu Undang-Undang Nomor 32 Tahun 2004, menekankan pentingnya otonomi daerah dalam rangka pemerataan pembangunan hingga kedaerah-daerah. Pelaksanaan pengendalian pengawasan yang dilakukan oleh DPRD Kabupaten Lamongan adalah dilakukan pada setiap program yang dimulai sejak perencanaan hingga ke perumusan dan sampai akhir tahun anggaran, hal tersebut dilakukan mulai :

a. Awal mulainya melalui penyusunan Panitia Anggaran dan alat perlengkapan Dewan yang lain.

b. Mengevaluasi laporan yangmasuk dari pelaksanaan di lapangan, bentuk dari laporan tersebut itu adalah laporan triwulan. Evaluasi tersebut dengan mengadakan koordinasi dengan jajaran instansi pemerintah.

c. Melakukan konsolidasi mendadak atau peninjauan mendadak ke lokasi yang menjadi obyek pemeriksaan.
\end{abstract}

\section{Kata Kunci : Dewan Perwakilan Rakyat Daerah (DPRD), Otonomi Daerah}

A. Pendahuluan

Latar Belakang Masalah

Sistem pemerintahan Indonesia dengan berdasarkan UUD 1945, memberikan keleluasaan kepada daerah untuk menyelenggarakan otonomi daerahnya. Kemudian guna menghadapi perkembangan yang ada, baik dalam maupun di luar negeri, serta persaingan global, maka dipandang perlu menyelenggarakan otonomi daerah dengan memberikan kewenangan yang luas nyata serta bertanggung jawab terhadap daerah itu sendiri secara proporsional.

Pemerintah daerah adalah Kepala Daerah beserta perangkat daerah otonom yang lain, disebut juga sebagai Badan Eksekutif Daerah. Dewan Perwakinil Rakyat Daerah, yang sering disebut DPRD adalah Badan Legislatif Daerah. Sedangkan yang dimaksud dengan Pemerintah Daerah adalah penyelenggara pemerintahan daerah otonom berdasarkan asas desentralisasi.

Dewan Perwakilan Rakyat Daerah adalah merupakan salah satu unsur Pemerintah Daerah yang keaggotaannya ${ }^{2}$ R N. Marbun, DPRD Pertumhuhan Masalah dan mencerminkan kondisi perwakilan rakyat Masa Depannya, Ghalia Indonesia, Jakarta, hlm 3 daerah yang diwujudkan dalam fraksi-fraksi dan bersama-sama dengan Kepala Daerah menjalankan tugas dan wewenang Pemerintah Daerah di bidang legislatif. ${ }^{1}$

Semenjak dahulu hingga sekarang keberadaan Lembaga Legislatif Daerah telah mengalami perubahan dan pengembangan yang sangat pesat, baik dari segi hukumnya maupun dari segi praktek lembaga daerah itu sendiri. ${ }^{2}$ Sebagai wakil rakyat di daerah, maka DPRD mempunyai tanggung jawab yang besar dalam mengemban aspirasi rakyat yang diwakilinya. Pembentukan Badan Perwakilan Rakyat Daerah dapat pula dikatakan sebagai perwujudan dari Pasal 18 UUD 1945 yang lebih lanjut diatur dalam Undang-Undang organiknya, yaitu UndangUndang Nomor 32 Tahun 2004, menekankan pentingnya otonomi daerah dalam rangka

${ }^{1}$ Achmad Fauzi dan Iskandar, Cara Membaca APBD, Universitas Sriwijaya, Malang, 192_ hlm Ma Depannya Ghatia Indonesia, Jakarta, hlm 3 
pemerataan pembangunan hingga kedaerahdaerah, demikian juga di daerah Kabupaten Lamongan. Hal ini didasarkan atas asumsi bahwa masyarakat daerah yang bersangkutanlah yang lebih tahu dan lebih mengerti dinamika daerahnya.

Dengan landasan itulah kemudian diletakkan hak dan wewenang pemerintah daerah otonomi dimana rakyat diikut sertakan, walaupun tidak secara keseluruhan. Badan Perwakilan Rakyat, yang merupakan perwujudan partisipasi rakyat dalam pemerintahan di daerah, yang merupakan perwujudan partisipasi rakyat dalam pemerintahan di daerah. Dalam Pasal 1 (b) Undang-Undang Nomor 32 Tahun 2004 tentang pemerintahan di daerah menyebutkan

a. Pemerintah Daerah adalah Kepala Daerah beserta Perangkat Daerah (otonomi yang selain sebagai Badan Eksekutif Daerah).

b. Dewan Perwakilan Rakyat Daerah selanjutnya disebut DPRD, adalah Badan Legislatif Daerah.

c. Pemerintah Daerah adalah penyelenggara Pemerintah Daerah Otononi oleh Pemerintah Daerah dan DPRD menurut asas Desentralisasi.

Mengenai ayat tersebut pemerintah daerah otonomi, demikian juga Pemerintah Daerah Kabupaten Lamongan berkewajiban memberikan keterangan dan pertanggung jawaban kepada anggota Dewan Perwakilan Rakyat Daerah tentang pelaksanaan pemerintahan di daerah. Badan Perwakilan Rakyat sebagaimana tersebut di atas yang kemudian disebut Dewan Perwakilan Rakyat Daerah untuk Propinsi, dibentuk DPRD Tingkat Propinsi dan DPRD untuk Kabupaten Kota, dibentuk DPRD Kabupaten/ Kota.

Disusunnya Badan-badan Perwakilan di Daerah bukan untuk menyusun dan membentuk atau mendirikan negara baru dan bukan juga untuk merubah UUD 1945, baik sebagian maupun keseluruhan, melainkan untuk menegakkan, mempertahankan, mengamalkan dan mengamankan, serta melaksanakan demokrasi sebagaimana yang telah diperjuangkan selama ini.

Bahwa sebelum adanya UndangUndang Nomor 32 Tahun 2004, kita ketahui bahwa peranan DPRD sangatlah minim.
Artinya seakan-akan pengawasan pelaksanaan DPRD hanya diberi cap persetujuan oleh para anggota DPRD tanpa adanya suatu pertimbangan. Dengan adanya Tap MPR Nomor XI/MPR/1998 tentang Penyelenggara Negara yang bersih dan bebas korupsi, kolusi, dan nepotisme serta melalui Undang-Undang Nomor 32 Tahun 2004 tentang Pemerintahan Daerah diharapkan peranan atau kinerja para anggota DPRD khususnya Kabupaten Lamongan berjalan dengan baik dan sesuai dengan harapan masyarakat Lamongan.

Diletakkannva hak dan wewenang Pemerintah daerah otonomi itu, dewan diikut sertakannya masyarakat, walaupun tidak secara keseluruhan. Oleh karena itu Dewan Perwakilan Rakyat Daerah merupakan lembaga yang cocok sebagai Badan Perwakilan Rakyat, yang merupakan perwujudan partisipasi rakyat dalam pemerintahan daerah.

\section{Perumusan Masalah}

Berdasarkan uraian latar belakang masalah diatas, dapatlah dirumuskan beberapa permasalahan sebagai berikut :

1. Bagaimanakah pelaksanaan pengawasan DPRD dalam penyelenggaraan Pemerintahan Daerah di Kabupaten Lamongan?.

2. Apakah faktor penghambat dari pelaksanaan pengawasan DPRD di Kabupaten Lamongan?.

\section{Tujuan Penelitian}

Berdasarkan rumusan masalah diatas maka tujuan penelitian yang dilakukan adalah sebagai berikut :

3. Untuk mengetahui pelaksanaan pengawasan DPRD dalam penyelenggaraan Pemerintahan Daerah di Kabupaten Lamongan.

4. Untuk mengetahui faktor penghambat dari pelaksanaan pengawasan DPRD di Kabupaten Lamongan.

\section{B. Kajian Teori} Pengertian Pemerintahan Daerah Pengertian Pemerintahan Daerah sebagaimana yang tersebut dalam ketentuan umum Undang-Undang Otonomi Daerah Nomor 22 tahun 1999 adalah 
penyelenggaraan Pemerintahan Daerah Otonom oleh Pemerintah Daerah dan DPRD menurut asas Desentralisasi. Sedangkan pengertian Pemerintahan Daerah menurut Undang-Undang Otonomi Daerah Nomor 32 tahun 2004 adalah penyelenggaraan urusan pemerintahan oleh Pemerintah Daerah dan DPRD menurut asas otonomi seluas-luasnya dalam sistem dan prinsip Negara Kesatuan Republik Indonesia.

Sedangkan pengertian Otonomi Daerah adalah yang memerintah dan mengurus daerahnya sendiri. ${ }^{3}$ Adapun yang dimaksud Otonomi Daerah menurut Undang-Undang Nomor 32 tahun 2004 adalah hak, wewenang, dan kewajiban daerah otonomi untuk mengurus sendiri urusan pemerintahan dan kepentingan masyarakat sesuai dengan peraturan perundang-undangan.

Dalam pasal 22 Undang-Undang Nomor 32 tahun 2004 menjelaskan bahwa dalam menyelenggarakan otonomi, daerah mempunyai kewajiban :

a. Melindungi masyarakat, menjaga persatuan, kesatuan dan kerukunan nasional, serta keutuhan Negara Kesatuan Republik Indonesia.

b. Meningkatkan kualitas kehidupan masyarakat.

c. Mengembangkan kehidupan demokrasi.

d. Mewujudkan keadilan dan pemerataan.

e. Meningkatkan pelayanan dasar pendidikan.

f. Menyediakan fasilitas pelayanan kesehatan.

g. Menyediakan fasilitas sosial dan fasilitas umum yang layak.

h. Mengembangkan sistem jaminan nasional.

i. Menyusun perencanaan dan tata ruang daerah.

j. Mengembangkan sumber daya produktif di daerah.

k. Melestarikan lingkungan hidup.

3 Daryanto SS. Kamus Bahasa Indonesia

Lengkap. Apollo. Bandung. 1997 hal 451
1. Mengelola administrasi pendidikan.

m. Melestarikan nilai sosial budaya.

n. Membentuk dan menerapkan peraturan perundang-undangan sesuai dengan kewenangan, dan

o. Kewajiban lain yang diatur dalam peraturan perundang-undangan .

Sistem pemerintahan Negara Kesatuan Republik Indonesia menurut Undang-Undang Dasar 1945 memberikan keleluasaan kepada daerah untuk menyelenggarakan Otonomi Daerah. Dalam penyelenggaraannya dipandang perlu untuk lebih menekankan pada prinsio-prinsip demokrasi, peran serta masyarakat, pemerataan dan keadilan, serta memperhatikan potensi dan keanekaragaman daerah.

Dalam menghadapi perkembangan keadaan, baik di dalam maupun di luar negeri serta tantangan persaingan global dipandang perlu menyelenggarakan Otonomi Daerah dengan memberikan kewenangan yang luas, nyata dan bertanggung jawab kepada daerah serta proporsional yang diwujudkan dengan pengaturan, pembagian, dan pemanfaatan sumber daya nasional serta perimbangan keuangan pusat dan daerah sesuai dengan prinsip-prinsip demokrasi, peran serta masyarakat, penerataan dan keadilan serta potensi dan keanekaragaman daerah yang dilaksamakan dalam kerangka Negara Kesatuan Republik Indonesia. Dengan demikian maka aturan-aturan yang berlaku di masing-masing daerah akan berbeda, sesuai dengan kondisi sosial budaya setempat.

\section{Pengertian Demokrasi Dan Perangkat Pendukungnya}

Sistem pemerintahan suatu negara ada yang mengakui hak segenap anggota masyarakat untuk mempengaruhi keputusan politik baik secara langsung maupun tidak langsung. Yang dimaksud dengaa demokrasi langsung, yaitu dimana suatu keputusan politik ditentukan oleh warga masyarakat dalam suatu pertemuan bersama, dan hanya dimungkinkan apabila jumlah penduduknya cuma sedikit. Demokrasi, langsung ini dilaksanakan pada masa dahulu, sedikit pengaruhnya terhadap perkembangan demokrasi perwakilan modern, dimana keputusan politik dilaksanakan oleh wakil- 
wakil yang dipilih dan bertanggung jawab kepada pemilih.

Demokrasi perwakilan ini, mulai dikenal dan berkembang di berbagai negara pada abad ke 18 dan abad ke 19 seperti halnya di negara Inggris, negara-negara Eropa Barat dan Amerika Serikat, dengan lembaga pusatnya adalah Dewan Perwakilan (Repressentative Parliament) dimana keputusan diambil menurut suara terbanyak. ${ }^{4}$

Lembaga pemilihan yang hakiki dalam demokrasi perwakilan adalah pemilihan secara teratur dengan kebebasan untuk memilih, hak pilih tersebut bagi orang dewasa, kebebasan untuk berbicara dan kebebasan pers, dan terakhir memelihara hak kemerdekaan sipil.

Demokrasi adalah suatu gejala masyarakat yang berhubungan erat dengan perkembangan suatu negara, mempunyai sifat dengan berbagai jenis, yang masing-masing terlihat pada sudut kemasyarakatan yang ditinjaunya terutama dalam keputusan para ahli di Perancis, berbagai sifat demokrasi itu dapat ditinjau seksama oleh para ahli ilmu kenegaraan. Pertama-tama pengertian demokrasi itu timbul bermacam-macam pendapat. Perkataan demokrasi berasal dan kata Demos berarti rakyat dan krateins berarti memerintah, yang maknanya adalah "Cara memerintah negara oleh rakyat". Perkembangan pengertiannya sendiri dari perkataan demokrasi yang pada asasnya tidak terjadi perubahan, yaitu suatu sistem pemerintahan dimana dipegang oleh rakyat atau setidak-tidaknya rakyat diikut sertakan dalam suatu pembicaraan masalah pemerintahan. Yang dimaksud dengan rakyat atau masyarakat negara disini adalah rakyat dalam arti keseluruhannya sebagai satu kebulatan. Akan tetapi akibat dari perkembangan zaman, sudah barang tentu membawa pengaruh terhadap cara-cara pemerintahan, sehingga menimbulkan perbedaan di dalam cara melaksanakan atas demokrasi tersebut di atas, asasnya sama tetapi cara mekanisme pelaksanaan pemerintahannya yang kemudian mengalami perbedaan.

\footnotetext{
${ }^{4}$ AW. Wijaya, Demokrasi dan Aktualisasi Pancasila, Penerbit Alumni, Bandung. 1984, hlm 5
}

\footnotetext{
5 Juniarto, Demokrasi dan Sistem Pemerintahan Negara, Bina Aksara, Jakarta, 1982, hlm. 2
}

Pemerintahan rakyat (demokrasi) ini dapat dilaksanakan dalam arti kata yang sebenarnya, artinya seluruh rakyat diikutsertakan dalam memecahkan persoalanpersoalan negara tersebut, yang penting yaitu dengan jalan mengumpulkan rakyat negara di dalam suatu tempat.

Untuk melaksanakan sistem ini tidaklah terlalu sulit, sebab dengan rakyat masyarakatnya yang tidak terlalu banyak dan begitu pula sifat dari pada persoalan negara itu sendiri masih sangat mudah dan sederhana, sehingga rakyat bisaa pun bisa diajak berbicara tentang persoalan atau permasalahan negara tersebut dan dapat mengerti pula akan persoalannya.

Demikian rumit dan berbelitbelitnya masalah negara yang ada pada saat sekarang, menyebabkan kesukaran bagi rakyat Mesa pada umumnya untuk mengerti persoalan yang sesungguhnya/ masalah pemerintahan tersebut. Make dicari jalan penyelesaiannya yaitu dengan sistem perwakilan rakyat dengan menunjuk wakil yang menjadi kepercayaannya untuk membawakan kemauan dan suara rakyat di dalam pemerintahan. Dengan demikian wakil-wakil rakyat inilah yang akan membicarakan masalah pemerintahan negara. Oleh karena itu timbullah asas sistem perwakilan.

Sistem perwakilan rakyat dalam arti dernokrasi ini dalam arti kata yang sebenarnya, seperti yang dipergunakan pada masa dahulu atau masa Yunani kuno yaitu rakyat secara menyeluruh memang benarbenar diajak serta dalam membicarakan masalah-masalah pemerintahan. Oleh karena itu sistem perwakilan rakyat pada masa dahulu disebut juga dengan sistem demokrasi secara langsung, sedang pemerintahan rakyat yang demokrasi dimana rakyat menunjuk wakil-wakilnya disebut demokrasi dengan sistem perwakilan. $^{5}$

Sedangkan perangkat dari demokrasi tersebut antara lain, rakyat yang diberi kebebasan dalam menjalankan hak asasinya dengan dilindungi aturan hukum yang jelas, sistem pemilihan wakil rakyat yang bebas, perangkat pemerintahan yang menjalankan 
harus adil, dan aturan perundang-undangan yang adil, tidak sebatas untuk orang atas saja.

\section{Tugas dan Wewenang DPRD Kabupaten Lamongan}

Tugas dan wewenang dari anggota

Dewan Perwakilan Rakyat Daerah Kabupaten Lamongan dalam pengawasan dan pengendalian terhadap jalannya Pemerintah Daerah Kabupaten Lamongan. Bentuk tugas anggota Dewan Perwakilan Rakyat Daerah Kabupaten Lamongan dalam melaksanakan tugasnya, antara lain : ${ }^{6}$

1. Membuat Peraturan bersama eksekutif, Peraturan tersebut berbentuk Peraturan Daerah/kesepakatan yang lain, ada juga yang berbentuk Surat Keputusan.

2. Disamping itu Dewan Perwakilan Rakyat Daerah melihat juga kinerja eksekutif, apakah sudah sesuai ataukah belum dengan Peraturan Daerah yang dibuat.

3. Peraturan Daerah antara lain tentang Rencana Strategis Pembangunan, APBD dan Perda yang berkaitan dengan pembentukan dinas-dinas di lembaga tersebut.

4. DPRD Kabupaten Lamongan melakukan juga penjaringan aspirasi warga apakah warga bisa menikmati otonomi daerah, sebagaimana yang telah digariskan ataukah tidak.

5. Kemudian hasil penjaringan disampaikan dalam rapat DPRD.

6. Mengikut sertakan masyarakat dalam proses pembahasan (meminta usulan/saran dari masyarakat, LSM dan Pemerintah Daerah)

7. Setelah itu DPRD sebagai representasi dari rakyat, maka proses pengambilan keputusan di DPRD tidak bisa meninggalkan suara dari masyarakat itu sendiri.

8. Permasalahan transplantasi, jadi tidak semua hasil yang diperoleh dari pengawasan oleh badan pemerintah daerah, BPKP, BPK, diberikan kepada DPRD sehingga seringkali anggota DPRD tidak tahu pasti hasil pemeriksaan yang sebenarnya.

\footnotetext{
${ }^{6}$ Sumber : Wawancara dengan Ketua Fraksifraksi DPRD Kabupaten Lamonganl, tanggal 23 Maret 2012.
}

9. Adakalanya keputusan yang telah disepakati bersama DPRD dengan Pemerintah tidak dapat diterima oleh sebagaian masyarakat.

10. DPRD Kabupaten Lamongan selalu memantau dan mengawasi jalannya otonomi di daerah dengan istansi-istansi di Kabupaten Lamongan melalui komisikomisi maupun melalui penerapan masyarakat.

11. Perundang-undangan yang dipakai DPRD dalam pengawasan, UU Nomor 32 Tahun 2004, PP 105 Tahun 2001, PP 108 Tahun 2001, dan PP 110 Tahun 2001.

12. Selalu mengadakan peninjauan di lapangan baik secara insidentil maupun secara rutin baik untuk mengantisipasi maupun mencegah bila terjadi permasalahan.

Adapun perundang-undangan yang dipakai oleh anggota DPRD Kabupaten Lamongan dalam melaksanakan tugas dan wewenangnya dalam masalah pengawasan, UU Nomor 32 Tahun 2004, PP Nomor 105 tahun 2001, PP Nomor 108 Tahun 2001, dan PP Nomor 110 Tahun 2001.

\section{Metode Penelitian}

1. Tipe Penelitian

Tipe penelitian hukum yang dilakukan adalah Yuridis Normatif. Metode penelitian hukum normatif adalah suatu prosedur penelitian ilmiah untuk menemukan kebenaran logika keilmuan dari sisi normatif ${ }^{7}$. Oleh karena itu, penelitian hukum ini difokuskan untuk mengkaji penelitian hukum tentang kaidah-kaidah atau norma-norma dalam hukum positif.

2. Pendekatan Masalah

Berawal dari tipe penelitian yang digunakan adalah tipe penelitian yuridis normatif, maka pendekatan masalah yang digunakan adalah

7 Johny Ibrohim, Teori Metode Hukum Normatif. Banyu Media Publishing, Malang tahun 2005 hal 47 
pendekatan perundang-undangan (Statute Approach). Pendekatan tersebut adalah dengan melakukan pengkajian perundang-undangan yang berkaitan dengan pokok permasalahan. Selain itu juga digunakan pendekatan analisa (Analisis Approach), pendekatan ini diterapkan kaitannya untuk mengkaji penerapan aturan-aturan hukum yang dilakukan dalam terapan atau praktik, sehingga diharapkan penerapan norma atau kaidah-kaidah hukum yang dipraktikkan sesuai dengan ketetapan.

3. Bahan Hukum

Sumber bahan hukum yang digunakan dalam penelitian ini adalah sebagai berikut :

a. Bahan Hukum Primer, yakni bahan hukum yang diperoleh dari peraturan perundang-undangan. Di antaranya : Undang-Undang Dasar 1945, Undang-Undang Nomor 32 tahun 2004 tentang Pemerintahan Daerah.

b. Bahan Hukum Sekunder, yaitu bahan hukum yang diperoleh dari buku teks, jurnal-jurnal, pendapat para sarjana, dan kasus-kasus hukum.

c. Bahan Hukum Tersier, yakni bahan hukum yang mengarah pada petunjuk atau penjelasan bermakna terhadap data primer dan sekunder, seperti kamus hukum, majalah, dan lain-lain.

4. Prosedur Pengumpulan Bahan Hukum Pengumpulan bahan hukum baik bahan hukum primer maupun bahan hukum sekunder dikumpulkan menurut topik permasalahan yang telah dirumuskan dan diklasifikasikan berdasarkan sumber dan hierarkinya untuk dikaji secara komprehensif.

5. Pengolahan dan Analisis Bahan Hukum

Adapun bahan hukum yang diperoleh dalam penelitian adalah studi kepustakaan dan aturan perundangundangan yang penulis paparkan dan dikaitkan sedemikian rupa, sehingga disajikan dalam penulisan yang lebih sistematis guna menjawab permasalahan yang dirumuskan. Cara pengolahan bahan hukum dilakukan secara deduktif yakni menarik kesimpulan dari suatu permasalahan yang bersifat umum terhadap permasalahan nyata yang dihadapi, selanjutnya dianalisa sehingga dapat diperoleh gambaran jelas tentang pengawasan DPRD terhadap penyelenggaraan pemerintahan daerah.

\section{Pelaksanaan Bentuk Pengawasan Yang Dilakukan Oleh DPRD Dalam Penyelenggaraan Otonomi Daerah di Kabupaten Lamongan.}

Kabupaten Daerah Lamongan adalah salah satu daerah Kabupaten di Indonesia yang diberi hak otonom, maka dalam hal ini Kabupaten Lamongan diberi wewenang dan mempunyai kewajiban mengatur rumah tangganya sendiri. Hak otonom merupakan realisasi dari system pemerintahan desentralisasi yaitu penyerahan urusan pemerintahan dari pemerintah atau daerah tingkat atasnya kepada daerah tingkat dibawahnya, menjadi urusan rumah tangganya sendiri sesuai dengan peraturan perundang-undangan yang berlaku.

Diambilnya sistem pemerintahan saat ini tidak lain adalah untuk tercapainya proses demokrasi dalam pemerintahan di daerah dan akan kesempatan yang lebih luas kepada rakyat untuk berperan serta dalam mewujudkan pembangunan. Sehingga dengan sistem tersebut, muncul daerah-daerah yang diberi otonomi untuk menyelenggarakan pemerintahannya sendiri.

Dengan demikian daerah otonom dalam menjalankan kewenangannya harus sesuai dengan kebijaksanaan dan kemampuannya sendiri dan ini dilakukan dengan biaya dari daerah sendiri. Sehingga perlu diadakan pengawasan yang dilakukan legislative daerah terhadap jalannya pemerintahan.

Pengawasan yang dilakukan oleh DPRD harus sesuai dengan nilai demokrasi rakyat, maksudnya dalam pengambilan Keputusan Pemerintah harus mendaya gunakan suara rakyat. Perangkat-perangkat yang mendukung nilai demokrasi, antara lain partai, lembaga-lembaga swadaya masyarakat 
yang ada di masyarakat. Lembaga yang ada dilingkungan masyarakat sebagai penyerap, penyalur aspirasi masyarakat dan kadangkadang juga menindak lanjuti jika terdapat permasalahan.

Berikut ini adalah Peraturan Perundang-undangan yang berkenaan dengan masalah otonomi di daerah, Undang-Undang Nomor 32 Tahun 2004, Undang-Undang Nomor 25 Tahun 2004, Undang-Undang Nomor 28 Tahun 2004, UndangUndang Nomor 4 Tahun 2004, Peraturan Pemerintah Nomor 105 Tahun 2004, Peraturan Pemerintah Nomor 106 Tahun 2004, Peraturan Pemerintah Nomor 107 Tahun 2004, Peraturan Pemerintah Nomor 109 Tahun 2004.

Didalam pembahasan peranan dalam pengawasan dan pengendalian DPRD yang diemban oleh DPRD, bisa dimaknai sebagai peran keperentaraan, DPRD bukan hanya menjadi perantara yang menjembatani ketegangan dari berbagai sekmen dalam masyarakat yang saling memperjuangkan kepentingannya sendiri. Terserapnya kepentingan masyarakat/partai kedalam lembaga perwakilan rakyat ini, secara normatif harus dimaknai mekanisme penyerapan konflik-konflik yang ada di masyarakat agar dapat dipecahkan secara politik melalui peran kepentaraan anggota DPRD. Pada sisi lain DPRD diberikan peran yang lebih luas menurut Undang-Undang Nomor 32 Tahun 2004, peran pengawasan terhadap kinerja Pemerintah Daerah. Peran pengawasan itu dilakukan oleh Dewan Perwakilan Rakyat Daerah berdasarkan Pasal 112 sampai Pasal 114 dimana disitu diatur mengenai pembinaan pengawasan penyelenggaraan Pemerintah Daerah dan Keputusan Dewan Perwakilan Rakyat Daerah Kabupaten Lamongan Nomor 09/KEP/DPRD/2004, pasal 4 sub e dimana disitu diatur mengenai : Melaksanakan, pengawasan terhadap :

1. Pelaksanaan Peraturan Daerah dan Peraturan perundang-undangan lain,

2. Pelaksanaan Keputusan Kepala Daerah,

3. Pelaksanaan APBD,

4. Kebijakan Pemerintah Daerah,

5. Pelaksanaan kerja sama internasional di Daerah.

Ad. 1, DPRD dalam melaksanakan pengawasan terhadap pelaksanaan
Peraturan Daerah dan Peraturan perundang-undangan lain, antara lain dengan melihat apakah yang dilakukan oleh Pemerintah Daerah sudah sesuai dengan mekanisme yang ada ataukah belum, serta apakah sudah sesuai dengan keadilan bagi masyarakat ataukah tidak. Contoh dari pelaksanaan ini adalah pelaksanaan pengawasan terhadap Peraturan Daerah Retribusi Parkir.

Ad. 2, Demikian juga dengan Keputusan Kepala Daerah, apakah di dalam melaksanakan kepemimpinannya sudah adil dan merata bagi masyarakat ataukah belum. Serta apakah, di dalam kepemimpinannya sudah sesuai dengan aturan mekanisme perundang-undangan yang ada, ataukah tidak. Bisa saja di dalam kepemimpinannya Kepala Daerah melakukan kesalahan seperti korupsi, kolusi ataupun nepotisme. Contoh Pelaksanaan ini adalah Surat Keputusan tentang Pengangkatan Camat atau pengangkatan Kepala Desa.

Ad. 3, Pengawasan DPRD dalam pelaksanaan APBD yaitu antara lain menerima rencana anggaran yang diajukan oleh Pemerintah Daerah, menyeleksi apakah benar-benar anggaran tersebut sudah sesuai dengan keperluan pembangunan daerah ataukah tidak (mengoreksi), mengesahkan anggaran yang diajukan oleh Pemerintah Daerah. Dan terakhir yaitu melakukan pengawasan dan koreksi selama pelaksanaan APBD, yaitu dengan melakukan sidak. Contoh dari pelaksanaan ini adalah pengawasan terhadap Pelaksanaan Peraturan Daerah Nomor 2 Tahun 2004 tentang APBD Kabupaten Lamongan Tahun 2004.

Ad. 4, DPRD dalam memperhatikan kebijaksanaan Pemerintah Daerah mekanisme/langkah-langkahnya hampir sama dengan tindakan yang dilakukan DPRD terhadap pengawasan lainnya. Contoh dari 
pelaksanaan ini adalah Pengawasan terhadap UU No. 25 Tahun 2004 tentang perimbangan keuangan.

Ad. 5. DPRD melakukan pengawasan terhadap pelaksanaan kebijaksanaan Internasional di Daerah, antara lain ikut melakukan penyusunan rencana kerja atau kontrak, melakukan pengesahan rencana kerja tersebut dalam Keputusan Daerah atau Keputusan DPRD, dan melakukan pengawasan dalam pelaksanaannya, apakah Pemerintah Daerah sudah sesuai dengan mekanisme aturannya yang ada, ataukah belum.

Disamping itu maksud dari pembinaan itu adalah, upaya memfasilitasi dalam rangka pemberdayaan daerah otonom. Sedangkan pengawasan lebih ditekankan pada pengawasan represif untuk lebih memberikan kebebasan kepada daerah otonom dalam mengambil keputusan serta memberikan peran kepada DPRD dalam mewujudkan fungsinya, sebagai pengawasan terhadap pelaksanaan otonomi daerah. Dalam hal itulah maka peraturan yang ditetapkan oleh daerah otonomi tidak memerlukan pengesahan terlebih dahulu oleh pejabat yang berwenang. Ketentuan dalam UndangUndang Nomor 2 Tahun 2004 itu memberikan gambaran bahwa mekanisme pengawasan di dalam Undang-Undang tersebut lebih sederhana, dalam upaya memberikan kemandirian dan keleluasaan bagi daerah untuk mengatur dan mengurus penyelenggaraan pemerintahan.

Dalam hal pengawasan ini kita kenal ada 2 bentuk pengawasan yaitu pengawasan yang bersifat preventif dan represif Pengawasan preventif mengandung prinsip bahwa Peraturan Daerah dan Keputusan Kepala Daerah mengenai pokok ketentuan baru yang berlaku setelah ada pengesahan pejabat yang berwenang, yaitu Menteri Dalam Negeri bagi Peraturan Daerah dan Keputusan Kepala Daerah.

Pengawasan represif dilakukan terhadap Peraturan Daerah dan Keputusan Kepala Daerah. Pengawasan ini berwujud, pembatalan Peraturan Daerah yang bertentangan dengan kepentingan umum dan peraturan perundang-undangan yang lebih tinggi tingkatannya. Pelaksanaan pengawasan yang berlaku pada Undang-Undang sebelumnya, berbeda dengan UU No 32 Tahun 2004 dimana pada Undang-Undang yang baru lebih bersifat represif, DPRD Kabupaten Lamongan dalam pelaksanaan pengawasan dan pengendaliannya terhadap eksekutif dituangkan dalam Keputusan DPRD Kabupaten Lamongan Nomor 09/KEP/DPRD/2004 tentang Tata Tertib DPRD Kabupaten Lamongan. Pengendalian dan pengawasan dilaksanakan sejak perencanaan setiap program dan kegiatan dimulai sejak perumusan APBD, pengawasan itu dilakukan melalui :

a. Melalui Panitia Anggaran dan alat perlengkapan Dewan yang lain turut aktif dalam menyusun rencanannya sampai pada pelaksanaan.

b. Mengevaluasi pelaksanaan APBD melalui Laporan Triwulan dengan mengadakan koordinasi dengan instansi Pemerintah Daeerah.

c. Melakukan tinjauan cadanga 1 pada obyek-obyek pelaksanaan program sambil menyerap aspirasi dan pendapat masyarakat.

d. Melaksanakan dan penetapan anggaran/pelaksanaan sisa anggaran.

e. Meminta pertanggungjawaban Bupati setiap akhir tahun anggaran.

f. Turut aktif dalam setiap merencanakan dan penetapan Peraturan Daerah.

Anggota DPRD Kabupaten Lamongan dalam melaksanakan tugasnya tersebut didukung dengan landasan peraturan perundang-undangan yang berlaku, yaitu :

a. Sebagai landasan kerja anggota DPRD telah dikeluarkan dengan adanya Surat Keputusan DPRD Kabupaten Lamongan Nomor 09/KEP/DPRD/2004, tentang Peraturan Tata Tertib DPRD Kabupaten Lamongan.

b. Bupati telah mempertanggungjawaban tugas kinerja Bupati kepada DPRD.

Mekanisme tersebut selain sederhana, juga memberikan hak kepada daerah untuk menyatakan keberatan atau ketidak setujuannya terhadap tindakan

\footnotetext{
${ }^{8}$ Sumber : Wawancara Dengan Anggota DPRD Kabupaten Lamongan, 23 Maret 2012
} 
pembatalan Peraturan Daerah atau Keputusan Kepala Daerah.

Tugas pokok DPRD adalah menetapkan kebijaksanaan Daerah, sedangkan tugas pokok Kepala Daerah adalah Sebagai pelaksanaan kebijaksanaan Daerah atau administator. Kebijaksanaan itu diwujudkan dalam bentuk Peraturan Daerah, maupun APBD. Disamping itu seperti tertera juga dalam Pasal 18 sub d dan e Undang-Undang Nomor 32 Tahun 2004, menyatakan bahwa DPRD menyusun APBD dan Peraturan Daerah. Kemudian dalam Pasal 43 sub g UU No 32 Tahun 2004 ditetapkan pula bahwa Kepala Daerah dengan persetujuan DPRD menetapkan Peraturan Daerah.

\section{B. Faktor Penghambat Dari Pelaksanaan Pengawasan DPRD}

Didalam pelaksanaan pengawasan yang dilakukan oleh DPRD Kabupaten Lamongan terhadap jalannya otonomi daerah di daerah Kabupaten Lamongan, khususnya yang dilaksanakan oleh jajaran Pemerintahan Daerah tentunya terdapat faktor-faktor yang mendukung dan faktor-faktor yang menghambatnya. Karena tidak mungkin sesuatu hasil yang baik bisa berjalan dengan baik tanpa adanya suatu permasalahan.

Oleh karena itu kita lihat faktorfaktor mana saja yang merupakan faktor pendukung dan faktor yang merupakan faktor penghambat. Faktor-faktor penghambat dalam pengawasan DPRD bisa saja disebabkan oleh kurangnya SDM jajaran aparatur Pemerintah Daerah sehingga pada waktu pengajuan rancangan suatu Peraturan Daerah yang bertujuan untuk otonomi daerah lebih dominan dilakukan oleh aparatur Pemerintah Daerah, pada hal sebagai wakil suara rakyat adalah suara dari anggota legislative, sehingga pengawasan yang dilakukan oleh DPRD tidak bisa berjalan dengan seoptimal mungkin. Kemudian faktor lain kemungkinan disebabkan oleh tanggung jawab jalannya otonomi daerah yang dilakukan oleh Pemerintah Daerah, seharusnya Pemerintah Daerah bertanggungjawab pada DPRD, tidak bertanggungjawab pada Pemerintah Pusat, sehingga hal tersebut menyulitkan pengawasan yang dilakukan oleh anggota legislative daerah.
Kemudian dilain pihak kita lihat faktor pendukung dalam pengawasan yang dilakukan oleh DPRD, yaitu salah satunya adalah perubahan peraturan perundangundangan yang berlaku pada saat ini. Yaitu Peraturan tentang otonomi daerah. Dalam perubahan tersebut kurang lebih sangat berpengaruh pada pengawasan yang ada, karena fungsi pengawasan yang dipunyai oleh DPRD lebih besar.

Disamping itu masih ada lagi salah satu fungsi DPRD yang bersifat mandiri yakni mengadakan pengawasan atas pelaksanaan kebijaksanaan daerah yang dilakukan oleh Kepala Daerah. Hal ini dapat disimpulkan dari ketentuan dari ketentuan dalam Pasal 18 sub f Undang-Undang Nomor 32 Tahun 2004. Jadi secara ringkas, DPRD mempunyai dua fungsi, yakni :

a. Sebagai partner Kepala Daerah dalam merumuskan kebijaksanaan daerah, dan

b. Sebagai pengawas atas pelaksanaan kebijaksanaan daerah yang dijalankan oleh Kepala Daerah.

Untuk menjalankan dua fungsi tersebut DPRD mempunyai kewenangan tertentu atau hak-hak untuk melakukan tindakan tertentu agar tugas/fungsi tersebut dapat berjalan dengan baik. Untuk melaksanakan fungsi pertama yaitu menetapkan peraturan Daerah dan APBD, DPRD mempunyai hak prakarsa, hak anggaran, dan hak amandemen, sedangkan untuk fungsi kedua yaitu menjalankan pengawasan, DPRD memiliki hak mengajukan pertanyaan bagi masing-masing anggota, meminta keterangan, mengajukan pernyataan pendapat, dan mengadakan penyelidikan.

Untuk dapat menentukan kebijaksanaan yang sesuai dengan kehendak rakyat yang diwakilinya, DPRD harus dapat memperhatikan kepentingan dan aspirasi rakyat. Kepentingan dan aspirasi rakyat ini beraneka ragam, baik karena jumlah rakyat yang sangat besar, maupun karena rakyat terdiri dari berbagai lapisan yang masingmasing mempunyai kepantingan sendirisendiri. Aspirasi atau kepentingan rakyat dapat terwujud material seperti sandang, pangan, papan, kesehatan dan seterusnya, maupun yang bersifat spiritual seperti pendidikan, kebebasan, keadilan, keagamaan, 
dan sebagainya. Kadang-kadang keinginan tersebut saling bertentangan satu sama lain.

Kepentingan rakyat tersebut akan dapat diselenggarakan dengan baik apabila wakil rakyat itu mengetahui aspirasi mereka yang diwakili dan kemudian mewakili kemampuan untuk merumuskan secara jelas dan umum serta menentukan cara-cara pelaksanaannya.

Untuk dapat merealisasikan fungsinya dengan baik, dengan sendirinya mutu atau kualitas anggota DPRD sangat menentukan. Penyusunan kebijaksanaan daerah yang tepat sangat tergantung pada kecakapan anggota DPRD untuk memecahkan masalah-masalah kehidupan yang dihadapi rakyat. Pengetahuan dan kecakapan itu diperoleh dengan melalui pendidikan dan pengalaman. Demikian juga dalam menjalankan fungsi pengawasan, maka diperlukan pula pendidikan dan pengalaman pendidikan, karena hal itu sangat penting sebab : ${ }^{9}$

a. Dapat memberikan pengetahuan yang luas dan mendalam tentang bidang yang dipilih atau yang dipelajari seseorang.

b. Melatih manusia untuk berpikir secara rasional dan menggunakan kecerdasan kearah yang tepat, melatih manusia menggunakan akalnya dalam kehidupan sehari-hari baik dalam berpikir, menyatakan pendapat rnaupun bertindak.

c. Memberikan kemampuan dan ketrampilan kepada manusia untuk merumuskan pikiran, pendapat yang hendak disampaikan kepada orang lain secara logis dan sistematis sehingga mudah untuk dimengerti.

Ketiga hal tersebut akan diperoleh anggota DPRD bila mereka memperoleh pendidikan yang cukup. Ketiga hal tersebut sangat penting bagi mereka agar dapat menjalankan tugasnya dengan baik.

Pengetahuan yang luas dan mendalam akan memberikan kemampuan untuk mengartikulasikan segala kepentingan rakyat serta menentukan cara yang lebih tepat dan efisien. Kemampuan berpikir secara rasional diperlukan untuk mempertimbangkan dan menilai berbagai kepentingan masyarakat dan cara-cara pelaksanaannya serta menetapkan kebijaksanaan Daerah berdasarkan urutan prioritas dan kemampuan dari Pemerintah Daerah. Ketrampilan untuk merumuskan pikiran logis dan sistematis diperlukan untuk merumuskan kebijaksanaan daerah, sehingga mudah dipahami oleh para pelaksanaan dan masyarakat umum. Hambatan-hambatan yang dihadapi anggota Dewan adalah : ${ }^{10}$

a. Belum terlambatnya izin yang diberikan Walikota,

b. Tidak siapnya obyek yang diteliti.

Oleh karena itu sebaiknya pihak Dewan Perwakilan Rakyat Daerah maupun Pemerintah Daerah mensosialisasikan terlebih dahulu setiap Peraturan yang dibuat, agar masyarakat memahaminya. Dan hendaknya setiap temuan yang didapat oleh Dewan Perwakilan Rakyat Daerah di lapangan di berita tahukan melalui media massa untuk supaya diketahui kepada masyarakat umum, supaya untuk mengetahui hasil kerja Dewan sebagai wakil rakyat.

\section{B. Penutup \\ Kesimpulan}

Dari tulisan tersebut di atas, maka penulis mengambil beberapa kesimpulan sebagai berikut :

1. Pelaksanaan pengendalian pengawasan yang dilakukan oleh DPRD Kabupaten Lamongan adalah dilakukan pada setiap program yang dimulai sejak perencanaan hingga ke perumusan dan sampai akhir tahun anggaran, hal tersebut dilakukan mulai :

a. Awal mulainya melalui penyusunan Panitia Anggaran dan alat perlengkapan Dewan yang lain.

b. Mengevaluasi laporan yangmasuk dari pelaksanaan di lapangan, bentuk dari laporan tersebut itu adalah laporan triwulan. Evaluasi tersebut dengan mengadakan koordinasi dengan jajaran instansi pemerintah.

c. Melakukan konsolidasi mendadak atau peninjauan mendadak ke lokasi yang menjadi obyek pemeriksaan.

\footnotetext{
${ }^{9}$ Sumber : Wawancara Dengan Anggota DPRD Kabupaten Lamongan, 23 Maret 2012
}

\footnotetext{
${ }^{10}$ Sumber : Wawancara Dengan Anggota DPRD Kabupaten Bojonegoro, 23 Maret 2012
} 
Disamping itu kita tidak bisa melupakan tugas dan kewajiban DPRD yang essensial, yaitu adalah membentuk komisi-komisi bidang pengawasan serta pengendalian yang hasilnya dilaporkan pada Sidang Paripurna Dewan untuk mengevaluasi hasil yang didapatkan di lapangan.

2. Faktor-faktor yang yang menghambat pelaksanaan pengawasan DPRD terebut adalah :

a. Kurangnya kualitas sumber daya manusia dari anggota Dewan, dibandingkan dengan aparatur Pemerintah Daerah.

b. Belum atau terlambatnya izin yang dibrrikan oleh jajaran Kepala Pemerintah Daerah, jika akan mengadakan pengawasan langsung.

c. Kurangnya pemahaman dari anggota Dewan akan obyek yang diteliti atau dengan istilah lain tidak siapnya obyek yang akan diteliti atau sedang diteliti.

\section{Saran}

1. Pihak Dewan Perwakilan Rakyat Daerah Kabupaten Lamongan hendaknya mensosialisasikan terlebili dahulu setiap Rancangan Peraturan Daerah yang akan dibuat atau disahkan, agar masyarakat lebih dapat memahami.

2. Hendaknya setiap temuan yan didapatkan oleh Dewan di lapangan diberikan ke mas media untuk diberitakan, agar masyarakat dapat mengetahui hasil kerja Dewan sebagai wakil rakyat.

\section{DAFTAR PUSTAKA}

\section{LITERATUR}

Achmad Fauzi dan Iskandar, Cara Membaca APBD, Universitas Sriwijaya, Malang

AW. Wijaya, Demokrasi dan Aktualisasi Pancasila, Penerbit Alumni, Bandung. 1984

Daryanto SS. KamusBahasa Indonesia Lengkap.Apollo. Bandung. 1997.

Juniarto, Demokrasi dan Sistem Pemerintahan Negara, Bina Aksara, Jakarta, 1982

JohnyIbrohim, TeoriMetodeHukumNormatif. Banyu Media Publishing, Malangtahun 2005

R N. Marbun, DPRD Pertumhuhan Masalah dan Masa Depannya, Ghalia Indonesia.

\section{PERATURAN PERUNDANG-UNDANGAN}

Undang-UndangDasar 1945.

Undang-UndangNomor 32 Tahun 2004, TentangPemerintahan Daerah. 